\title{
Theoretical and practical aspects of the evaluation of health-related quality of life (HRQOL)
}

\section{Teoretyczne i praktyczne aspekty oceny jakości życia w ujęciu zdrowia (HRQOL)}

\author{
Monika Zarębaํㅗ Anita Zaręba², Andrzej Jopkiewicz³, Agata M. Jopkiewicz \\ ${ }^{1}$ Collegium Medicum, Jan Kochanowski University, Kielce, Poland \\ Head of the Collegium: Prof. Marianna Janion, MD, PhD \\ ${ }^{2}$ Holycross Cancer Centre, Kielce, Poland \\ Head of the Department: Jarosław Jaskulski MD, PhD, FEBU \\ ${ }^{3}$ Professor Emeritus JKU, Department of Auxology, Jan Kochanowski University, Kielce, Poland \\ ${ }^{4}$ Department of Adults Education, Jan Kochanowski University, Kielce, Poland \\ Head of the Department: Agata Chabior PhD, Prof. JKU
}

Medical Studies/Studia Medyczne 2021; 37 (4): 338-343

DOI: https://doi.org/10.5114/ms.2021.112390

Key words: health-related quality of life (HRQOL), quality of well-being scale (QWB), World Health Organization quality of life instruments (WHOQOL-BREF).

Słowa kluczowe: jakość życia w ujęciu zdrowia (HRQOL), kwestionariusze oceny (QWB), World Health Organization quality of life instruments (WHOQOL-BREF).

\begin{abstract}
The aim of this paper is to present various theoretical and practical aspects of health-related quality of life (HRQOL). Clinical studies show that, along with the classic quantitative indicators of treatment success regarding the patient's life expectancy, the parameters of quality of life, which include, among others, a reduced number of symptoms of disease, improved wellbeing and mood, as well as physical fitness, are of great importance. The interest in the problem of quality of life is also conducive to the development of new research tools. However, it should be remembered that regardless of the tool used, the quality of life felt by the patient is individual and changes over time. The ease of use of questionnaires and analogue scales allows us to obtain various types of information, provided that certain criteria are met.
\end{abstract}

\section{Streszczenie}

Celem tej pracy jest przedstawienie różnych teoretycznych i praktycznych zagadnień oceny jakości życia w ujęciu zdrowia (HRQOL). Badania kliniczne wskazują, że na równi z klasycznymi, ilościowymi wskaźnikami powodzenia terapeutycznego, dotyczącymi długości życia chorego, ogromne znaczenie mają parametry jakości życia, na które składają się między innymi zmniejszona liczba objawów chorobowych, poprawa samopoczucia i nastroju oraz sprawność ruchowa. Zainteresowanie problemem jakości życia sprzyja także powstawaniu nowych narzędzi badawczych. Należy jednak pamiętać, że niezależnie od zastosowanego narzędzia jakość życia odczuwana jest indywidualnie i zmienia się w czasie. Łatwość w stosowaniu kwestionariuszy oraz skal analogowych pozwala uzyskać różne informacje, ale pod warunkiem spełnienia przez nie określonych kryteriów.

\section{Introduction}

Health coexists with illness. The relationship between these 2 conditions is complex and intertwined. The saying: 'more health - less disease, and vice versa', in which many people, including some researchers, believe, does not seem to be true. Studies on common knowledge of health show that health and disease are not mutually exclusive categories in people's minds. One can be disabled and feel healthy, one can be objectively healthy and feel sick; hence, people usually do not define themselves as unequivocally healthy or sick [1].
This understanding of health was adopted by the World Health Organization (WHO) in its constitution as early as in 1946. It defines health in terms of positive health, describing it as a state of complete physical, mental, and social well-being and not merely the absence of disease or infirmity. This postulate, that health should be understood not only as the absence of disease, but also as well-being in a general sense, allows us to distinguish various spheres of health - not only physical, mental, and social, but also intellectual or spiritual. It has also contributed to the awareness of the need for a different perspective on health as- 
sessment [2], as well as the questioning of conservative health assessment methods and the possibility of holistic care in relation to the biomedical component of patient care [3].

Modern medicine focuses on the quality of life of the patient, taking into account the effectiveness of treatment, including the improvement of quality of life and individual assessment of their health condition. Hence, the aim of this work is to present various theoretical and practical aspects of health-related quality of life.

\section{Theoretical aspects of HRQOL}

The increased interest in the quality of life of patients, struggling with various diseases, increases with the development of civilization and the extension of life expectancy. Hence, when examining the clinical effects of chronic diseases, in addition to assessing the biological state of a patient's health, other factors are taken into account, with special attention paid to the emotional sphere, feelings, and quality of life. Moreover, it was found that the biological criterion for the assessment of treatment effectiveness is insufficient, and hence the interest of medicine in other tools of health assessment, regarding patients' activities in various spheres of life, has developed [3].

Focusing on the patient's quality of life means that the effectiveness of treatment is evaluated by the improvement of functioning in everyday situations and self-assessment of the patient's health condition. The need for a different view of health assessment is related to questioning conservative methods of assessment, combined with the possibility of holistic care in relation to the biomedical element of patient care [3].

Research on the quality of life of patients results in the need to consider other areas of life, previously overlooked in clinical assessments of the patient's disease. It has been noticed that in clinical assessments, along with the classic quantitative indicators of treatment success that measure the patient's life expectancy, the parameters of quality of life, which include, among others, a reduced number of symptoms of disease, improved well-being and mood, as well as physical fitness, are of great importance.

Although many sciences research quality of life, such as economics, social sciences, psychology, or medicine, no theoretical model fully defining the concept of quality of life has been developed so far. There are also discrepancies in the definition or construction of measurement tools, which makes it difficult to compare results. Hence, the concept of quality of life is described in normative, phenomenological, empirical, and relational terms [3].

The 'quality of life' of a person, in the broad sense of the term, expresses prosperity, life satisfaction, happiness, or lack of it. Thus, the issue of quality of life is analysed using the following 2 models. The first is a model of the needs of a person, and it asks whether quality of life helps or hinders the fulfilment of those needs. The second model is based on the assessment of health, i.e. various somatic and psychopathological symptoms, including sexuality, activity, and a sense of satisfaction [3].

In psychology, 'quality of life' is treated as subjective feelings, experiences of an individual based on the experiences of everyday life, affecting life satisfaction and mood. Social sciences emphasize the importance of analysing subjective-objective determinants, whereas quality of life in medicine most often refers to the aforementioned definition of health adopted by the WHO. Therefore, 'quality of life' cannot be identified with one concept, e.g. lifestyle, mental state, sense of well-being, health, but must be understood as an array of factors influencing it. Pioneers in the field of medicine are Karnofsky and Burchenal [4], the creators of a scale for measuring the quality of life of patients and their physical fitness. Therefore, the result of patient treatment, according to these authors, should not only be a subjective improvement, but also an objective improvement in activity and physical fitness [4].

In psychology, 'quality of life' is most often defined in relation to the theory of needs, or values and motivations, considered in the philosophical aspect. Therefore, a new research approach is needed, focusing attention on life experiences and events influencing the course of a person's life, which are seriously affected by a specific somatic disease. Somatic disease significantly burdens the mental state, which is the result of physical and social ailments, as well as fear for health or even life. Hence, according to Schipper [5], the quality of life may be the result of mathematical calculations in which appropriate research tools are used.

According to de Walden-Gałuszko and Majkowicz [6], quality of life is the perception of one's own situation at a specific time. Therefore, these authors perceive the essence of medical research on quality of life from 2 perspectives: firstly, the reality in which the patient lives and secondly, self-evaluation conditioned by individual experiences and views. With this approach, the dependence of quality of life on the sense of happiness is highlighted, because in each disease and its treatment there are obstacles to achieving the intended goals and satisfying the patient's needs.

Schipper [5] emphasizes that quality of life depends both on the state of human health and existing diseases, as well as on the natural aging process. Thus, the quality of life consists of 3 coherent elements [7, 8]: - physical indicators (disability, pain),

- mental conditions (well-being, degree of anxiety, states of depression),

- social (the degree of isolation from the environment, the ability to fulfil social roles, etc.).

Because the concept of quality of life in various theoretical papers assumes different meanings, defining quality of life as a subjective mental state of 
an individual makes it possible to recognize that the sense of quality of life is the result of the objective conditions of a patient's life, their personality traits, and their behaviour. An objective approach to quality of life is usually associated with the quantification of its scale. On the other hand, understanding quality of life as the subjective feeling of an individual means that the only person deciding about the feeling is that person [9].

There is no doubt that quality of life is a multidimensional concept resulting from different manners in understanding this issue $[10,11]$. It is of utmost importance that this concept should include dimensions essential for the patient, namely $[3,11]$ : health care, i.e. easing symptoms and pain; functioning in everyday life; family life; satisfaction; spirituality; social life; satisfaction with treatment; prognosis for the future; and sexuality and intimacy. Hence, attention in medical research focuses on definitions that distinguish 5 basic dimensions of HRQOL because they cover a broad spectrum of important aspects of human activity. These dimensions are: physical, mental, cognitive and social functioning, and a sense of well-being $[3,7,11]$. There is a belief that changes in HRQOL resulting from the disease and treatment may have a positive and negative effect. Therefore, research and clinical practice in relation to the established criteria for assessing quality of life take into account both subjective and objective aspects.

In the case of the objective assessment of quality of life, the assessment consists of objective variables that are directly evaluated by the researcher, such as: physical and mental health, medical examination results, symptoms and diagnosis. The subjective assessment, on the other hand, is based on objective and subjective variables, which are assessed by the researcher on the basis of the patient's subjective perceptions and feelings, and therefore the patient's knowledge, views on ailments, the body's capacity and its functioning, as well as the emotional relationship to the disease and treatment. Among the supporters of estimating objective measurements, there is an opinion that the patient's assessment is not as important as the doctor's, because the patient does not have the factual knowledge necessary to assess his/her own health condition.

The factors that significantly differentiate HRQOL include age, sex, and the level of education. Hence, the quality of life clearly deteriorates with age in both women and men over 60 years of age. However, women usually evaluate their quality of life as lower, which may be related to the fact that they live longer and may suffer from loneliness. On the other hand, women are characterized by a greater biological resistance to the influence of favourable and unfavourable external factors.

Women are also characterized by greater health awareness and care for health, related to the earlier course of the processes of sexual maturation, the monthly cycle, and the period of puerperium and childbirth. Therefore, the average life expectancy of women is longer than that of men, which is related to their more healthy lifestyle compared to men.

According to various authors, quality of life is as follows [2]: no burden, no ailments or difficulties; a very complex and subjective assessment of contentment and satisfaction with life, including all its spheres; a subjective opinion on one's own life situation, which is expressed by a person in a certain period of time; a subjective sense of satisfaction with the current life situation in the context of opportunities and needs; personal view of social status, in the context of culture and system of values, in relation to the set of goals and expectations; the difference between what has been achieved and what the person believes is achievable.

Often these definitions are descriptive, and they describe quality of life in a holistic way, more generally, assuming that it includes all spheres of well-being important to people. It is how we imagine coping with life; our own satisfaction and a sense of happiness in spheres of life that a person considers a priority; high level of awareness and activity; a variety of life goals and experiences [2]. It is a broad concept that is influenced by physical and mental health, social relations, the degree of independence, and the attitude of the individual to the important features of the environment in which they live [2].

All common features included in those definitions determine quality of life in the context of meeting the needs of a person, family, or community, both material and non-material needs. Therefore, quality of life is determined by the relationship between the individual's motivational sphere, along with the possibility of satisfying needs at the same time. It is known that the needs of a physiological nature must be met, while those defined as of higher order may or may not develop.

Hunt and Mc Kenna [3] selected the following needs, which, in their opinion, constitute the quality of human life: biological needs, safety, love, intimacy, sharing experience, striving for a goal, communication, curiosity, recognition, sense of usefulness, selfesteem, freedom and independence, and self-development. Hence, the sense of quality of life is a derivative of these reflections, and the measure is expressed as emotional satisfaction $[3,7]$.

To sum up, it should be noted that defining quality of life is becoming more and more popular, mainly due to the appreciation of the value of a reliable indicator, and its usefulness in treatment is growing. The great interest in the quality-of-life problem fosters the emergence of new research tools, mostly in the form of questionnaires and analogue scales. It is important, however, that regardless of the questionnaire used, 
quality of life is experienced individually and changes over time. The ease of use of these tools allows for various kinds of information, provided that they meet certain criteria, in particular: accuracy, reliability, sensitivity, and repeatability $[2,3,7,11,12]$.

\section{Practical recommendations}

Methods for measuring quality of life in relation to health are employed to assess HRQOL and are usually tailored to the study of a specific problem, i.e. a specific disease. One-dimensional or multi-dimensional general analysis tools measure different aspects of HRQOL and relate to different aspects of activities of a person. On the other hand, one-dimensional specific analysis tools are used to assess one aspect or several aspects, and they are considered less precise because they are characterized by a lower level of validity and reliability. They are in contrast to multidimensional scales that are more precise and allow for multidimensional assessment of quality of life $[2,12,13]$.

There is no doubt that questionnaire methods are most often used in HRQOL assessments because they are mainly based on the self-assessment of the respondent. They can be conducted in the form of an interview with the patient or an auditorium survey because this assessment is based on the subjective assessment of the subject. It is advisable that only the patient as an individual should perform the assessment, because they can most accurately assess the quality of their life [13].

Nowadays, the most frequently used research tool referred to in literature is the WHOQOL-100 (WHO Quality of Life Questionnaire) [13]. Unfortunately, there are practically no Polish population-focused tools for assessing quality of life because the WHOQOL-100 is a WHO questionnaire intended mainly for the diagnosis of the quality of life of a person resulting from a specific disease and its treatment. It contains a total of 100 questions on the positive and negative aspects of quality of life, using a 5-point Likert scale. According to the WHOQOL-100 instruction, the response values are from 4 to 20 points, and a higher value means a better quality of life [13]. The research covers 6 main areas: physical; mental; the level of independence; social life; favourable environment; and spiritual aspects [13]. It should be emphasized that this questionnaire contains high psychometric parameters, which were determined on the basis of various international studies.

In the case of the general assessment of quality of life, in terms of HRQOL, Short Form 36 (SF-36) is also used, which consists of 36 questions in 8 categories that relate to both mental and physical health $[7,13,14]$.

These categories include the spheres of physical and social functioning, as well as physical and emotional limitations, the mental sphere, the perception of health in general, ailments related to physical pain, and life energy. They are intended to assess health in a variety of medical and psychosocial categories.

Another assessment tool is the QWB questionnaire, which is one of the methods of quantifying quality of life. Its creators are Kaplan et al. [9], who adopted the measurement of a quality of life indicator for the general population in a given area and for specific social groups as their main goal. It consists of part A, which assesses 3 groups of human activity, and part B, which assesses the occurrence of a total of 22 groups of different somatic and mental symptoms [9].

The Nottingham Health Profile (NHP), on the other hand, is used to measure health problems experienced by the patient and their impact on daily life. It is also used to assess the quality of life of a given population and people with specific health problems in the physical, mental, and emotional spheres. Before starting the survey, as an introduction, the respondent presents his/her subjective opinion about his/her own health on a scale from very good to very poor [10, 11]. In the first part of the questionnaire, 38 questions in 6 categories are used to assess the patient's daily functioning, as well as sleep, energy, emotional reactions, social isolation, physical fitness, and pain. These questions are intentionally arranged alternately so that the respondent answers them as honestly as possible and marks a probable answer $[9,10]$. Therefore, this questionnaire is one of the most popular tools for assessing the patient's quality of life.

The level of human efficiency in relation to everyday life activity is characterized by Karnofosky's Performance Status (KPS), which assesses 2 levels, i.e. the patient's independence and self-sufficiency in meeting personal needs, as well as their dependence on constant medical care [15]. Thus, the patient's state of health is shown on a numerical scale and the level by percentage indicators from $100 \%$ to $0 \%$. A higher score on the scale means a better quality of life, while a low score indicates a worse quality of life [16].

Other tools [17] may also be used to assess the quality of life, e.g. to assess physical fitness of adults and the elderly. An example of a tool in the field of physical fitness is the Fullerton Functional Fitness Test (FFFT), which was developed in the USA to assess the physical fitness of people over the age of 60 years. It consists of 5 tests that enable the assessment of strength and flexibility of the lower and upper body parts, as well as endurance [17]. On the other hand, in terms of the assessment of physical capacity, the Wahlund-Sjöstrand method can be used, i.e. the PWC170 or PWC150 exercise test performed on a cycle ergometer or treadmill. Determining this value is a simple and safe method with good repeatability because there is a high correlation between the test results and VO2max [17].

Usually, the quality of life is assessed using standard research questionnaires, and commonly used one is the questionnaire developed by the WHO with 
the acronym WHOQOL-BREF. It contains 26 questions that allow for the simultaneous assessment of the quality of life in the somatic, social, environmental, and psychological spheres, the reliability of which is sufficient [16].

There are also health questionnaires for children and adolescents, including KIDSCREEN-52 [18] which aims to measure health-related quality of life in 8-18-year-olds. The questions concern: physical and mental well-being, moods and emotions, selfperception, autonomy, family and home life, financial resources, social and peer support, school environment, and social acceptance. The theoretical model of this questionnaire is based on the self-assessment of health. It can be used both for healthy and sick people; therefore, 13 versions of this questionnaire were developed, taking into account the specificity of the language and culture [18].

To measure quality of life the method of Schipper et al. is also in use [19]. They developed a 10-point scale in the form of a ladder, where the very bottom of the ladder means the worst quality of life, the top the best, and the intermediate rungs mean life equally close to the best or worst. Taking into account the self-assessment of the quality of life 5 years ago, in 5 years' time, and at present, the quality-of-life quotient can be calculated. Studies conducted with the use of this method show that the quality of life clearly deteriorates with age in women and men over 60 years of age. However, women generally evaluate their quality of life as poorer, which may be related to their longer survival, as well as loneliness [20]. Moreover, there are significant differences in the sense of quality of life depending on the level of education, because people with lower education more often show dissatisfaction. Interestingly, this phenomenon is more pronounced in women [20]. This is because education is a variable related to the relation of an individual to the values and culture concerning direct associations in the sphere of expected goals and established standards [21]. Hence, the health-related recommendations of the European Union emphasize the need to improve the quality of life, especially in patients suffering from various chronic diseases.

\section{Summary}

There is no doubt that the objective quality of human life is determined by many factors, in particular: standard of living, housing conditions, medical care, ecology, social life, education, professional work, personal development, participation in culture, leisure in the full sense of the word, recreational physical activity, etc. The subjective quality of human life is determined by fulfilling needs such as: security, peace of mind, self-acceptance, social recognition, and realization of life goals and desires.

Subjective human needs, related to self-fulfilment or the degree of satisfaction with one's cultural life, are beyond objective measures. As a result, in recent years, there has been a tendency to attach more and more importance to subjective indicators because it is believed that, contrary to objective indicators, they reflect not only the existing phenomenon analysed in the context of a specific disease, but also the situation directly related to the patient.

The concept of quality of life assumes different meanings in various scientific papers. When it is assumed that quality of life is a subjective mental state of an individual, it is then a resultant of the objective conditions of a patient's life, his/her personality traits, and behaviour. An objective approach to quality of life is usually associated with the quantification of its scale. On the other hand, understanding quality of life as the subjective feeling of an individual means that the only person deciding about the scale of quality of life is the person in question.

\section{Acknowledgments}

Project financed under the program of the Minister of Science and Higher Education called "Regional Initiative of Excellence" in the years 2019-2022, project no. 024/RID/2018/19, amount of financing $11999000,00 \mathrm{zł}$.

\section{Conflict of interest}

The authors declare no conflict of interest.

\section{References}

1. Sęk H. Podstawy tworzenia wskaźników zdrowia - perspektywa psychologii zdrowia. In: Współczesne potrzeby i możliwości pomiaru zdrowia. Karski JB, Kirschner H, Leowski J. Ignis, Warsaw 1997; 19-30.

2. Fraser S. Quality of life measurement in surgical practice. Br J Surg 1993; 80: 163-169.

3. Hunt S, McKenna S. European Guide to the Nottingham Health Profile. The European Group for Quality of Life and Measurement 1992.

4. Karnofsky DA, Burchenal J. The clinical evaluation of chemotherapetic agents in cancer. In: Evaluation of Chemotherapeutic Agents in Cancer. Mc Leod CM (ed.). Columbia Univ Press, NY 1949; 191-196.

5. Schipper H. Quality of life: principles of the clinical paradigmat. J Psychosoc Oncol 1990; 8: 171-185.

6. de Walden-Gałuszko K, Majkowicz M. Jakość życia w chorobie nowotworowej. Wyd. UG, Gdańsk 1994.

7. Miniszewska J, Chodkiewicz J, Zalewska-Janowska A. Jakość życia w zdrowiu i chorobie - czym jest, jak i po co ją oceniać. Przegl Lek 2012; 69: 253-259.

8. Andresen E, Rothenberg B, Kaplan R. Performance of a self-administered mailed version of the Quality of Well-Being (QWB-SA) questionnaire among older adults. Med Care 1998; 36: 1349-1360.

9. Kaplan R, Siebier W, Ganiats T. The quality of well-being scale: comparison of the interviewer - administered version with a self-administered questionnaire. Psychol Heal 1997; 12: 783-791. 
10. Stelcer B. Psychologiczny wymiar pojęcia jakości życia. In: Postępy pielęgniarstwa i promocji zdrowia. Wołowicka L (ed.). Wyd. AM, Poznan 1997, 156-160.

11. Hunt S, Mckenna S, McEwen J, Williams J, Papp E. The Nottingham health profile: subjective health status and medical consultations. Soc Sci Med 1981; 15: 221-229.

12. Dziurowicz-Kozłowska A. Wokół pojęcia jakości życia. Psych Jakości Życia 2002; 1: 77-99.

13. Skevington SM, Lotfy M, O`Connell KA. The World Health Organization`s WHOQOL-BREF quality of life assessment: Psychometric proporties and results of the international field trial. A Report from WHOQOL Group. Qual Life Res 2004; 13: 299-310.

14. Wołowiecka L. Jakość życia w naukach medycznych. AM, Poznań 2002.

15. Schag CC, Heinrich RL, Ganz PA. Karnofsky performance status revisited: reliability, validity, and guidelines. J Clin Oncol 1984; 2: 187-193.

16. Nordenfelt L. Quality of life, health and happiness. Averbury, Aldershot 1993.

17. Jopkiewicz A, Suliga E. Biomedyczne podstawy rozwoju i wychowania. ITE, Radom-Kielce 2011.

18. Oleś M. Jakość życia u dzieci i młodzieży - przegląd metod pomiaru. Przegl Psychol 2010; 53: 211-238.

19. Jopkiewicz A. Próba oceny zmian starczych oraz jakości życia i zaradności życiowej u osób po 60. roku życia. [In:] Człowiek stary $\mathrm{w}$ rodzinie - o trudnym problemie przemocy wobec starszych. Matyjas B, Gościniewicz M (eds.). Wyd. UJK, Kielce 2011; 39-52.

20. Jopkiewicz A. Samoocena zdrowia, jakości życia i zaradności życiowej osób starszych. Rocz Lubuski 2014; 40: 261-273.

21. Hayo B, Seifert W. Subjective economic well-being in Eastern Europe. J Econ Psych 2003; 24: 329-348.

\section{Address for correspondence:}

Dr. Monika Zaręba

Collegium Medicum

Jan Kochanowski University

Kielce, Poland

Phone: +48660785086

E-mail: monikazareba@op.pl 